
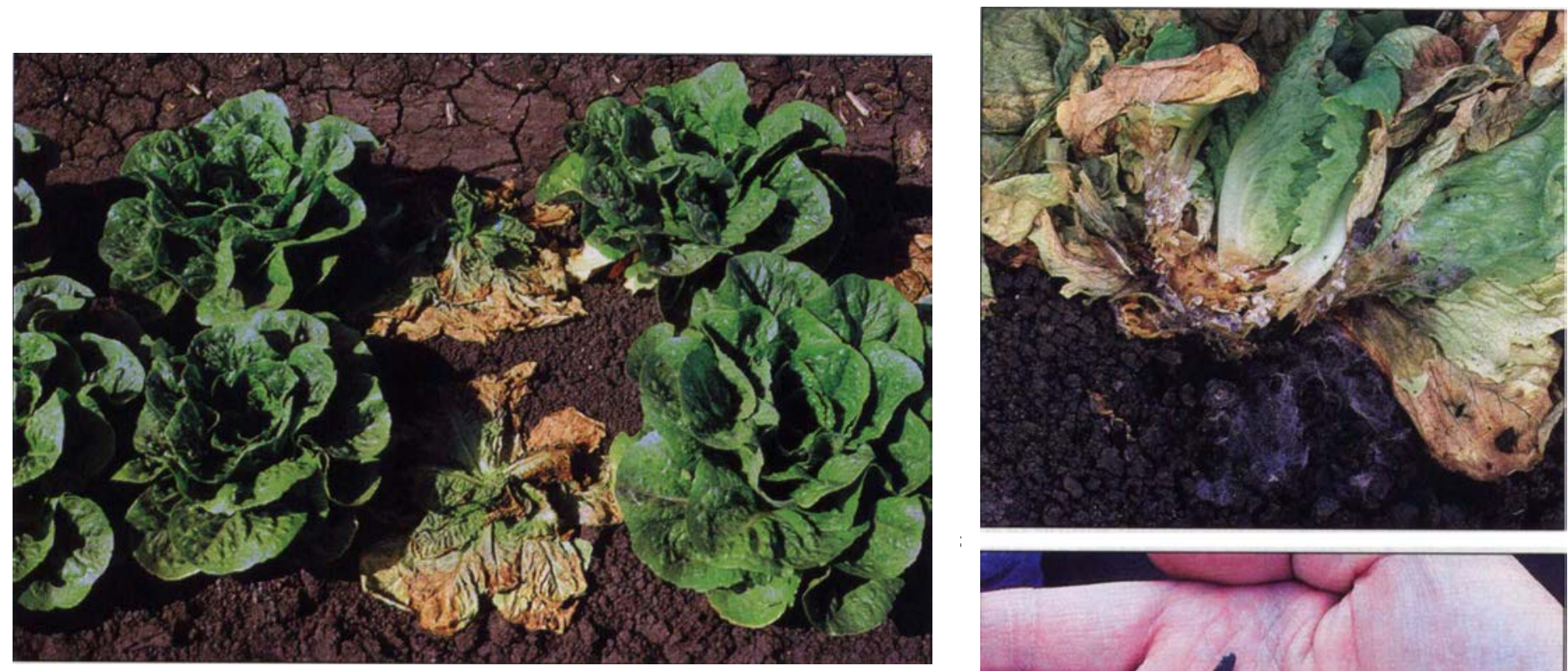

A Symptoms of lettuce drop include drying of older leaves, collapse of the plant, decayed crown tissue and plant death. The characteristic white mycelium and black sclerotia are usually present on the infected crowns (photo above right)

Sclerotia of Sclerotinia sclerotiorum (left) and S. minor (right) enable the pathogen to survive in soil. Although both species cause lettuce drop disease, $\mathbf{S}$. minor is the principal lettuce drop pathogen in the coastal region of California.

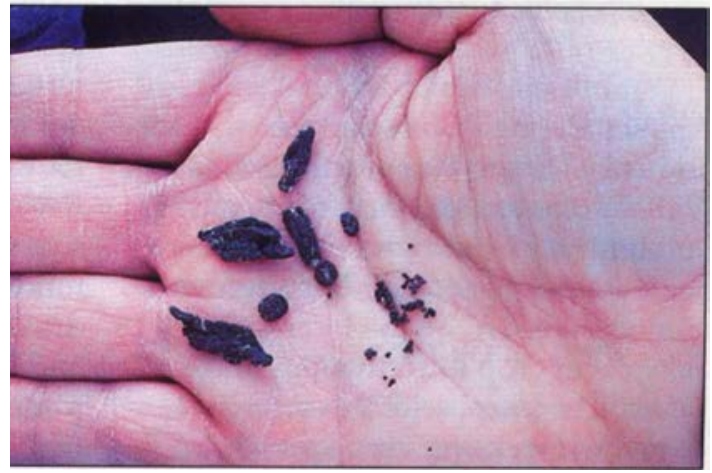

\title{
Cover crops can increase lettuce drop
}

\author{
Steven T. Koike $\square \quad$ Richard F. Smith \\ - Louise E. Jackson \ Lisa J. Wyland
}

William E. Chaney a John I. Inman

\begin{abstract}
Although cover crops contribute many benefits to organic and conventional agricultural systems, they may play a significant role in the epidemiology of soilborne diseases. A 2-year study shows that Sclerotinia minor, which causes lettuce drop disease, is a pathogen of phacelia, lana woollypod vetch and Austrian winter pea cover crops. Greenhouse and field inoculations failed to result in $\mathrm{S}$. minor infections of oilseed radish, barley and fava bean cover crops. It appears these three cover crops can be safely incorporated into lettuce rotations without increasing the occurrence of lettuce drop.
\end{abstract}

In recent years, the emphasis on sustainable agriculture and sound farming practices has encouraged vegetable growers in the Central Coast to increase the planting of winter cover crops. These cover crops offer a wide range of benefits to both organic and conventional farming systems, such as the addition of organic matter to soil, improvement of soil structure and water penetration, reduction of soil erosion, contribution of nutrients for subsequent crops and reduction of nitrate loss from leaching during winter rains. In addition, some cover crops can function as trap crops, which reduce soil populations of plant parasitic nematodes, and as sources of natural compounds, such as glucosinolates, that can kill or suppress soil pathogens, nematodes and weed seeds.
However, the use of cover crops also imposes a cost. Expenditures for seed, soil preparation and irrigation water must be added to farming budgets. As a nonharvested crop, cover crops bring in no receipts to offset land rents, and in fact they occupy a cropping period in which a winter vegetable crop could be grown. In addition, cover crops can exact biological costs if they act as reservoirs for insects, pathogens, rodents and other pests.

Growers in the Salinas Valley are planting newly used winter cover crops such as phacelia (Phacelia tanacetifolia) and oilseed radish (Raphanus sativus). However, the impacts of these and other cover crops on populations of Sclerotinia minor, the causal agent of lettuce drop, are not 

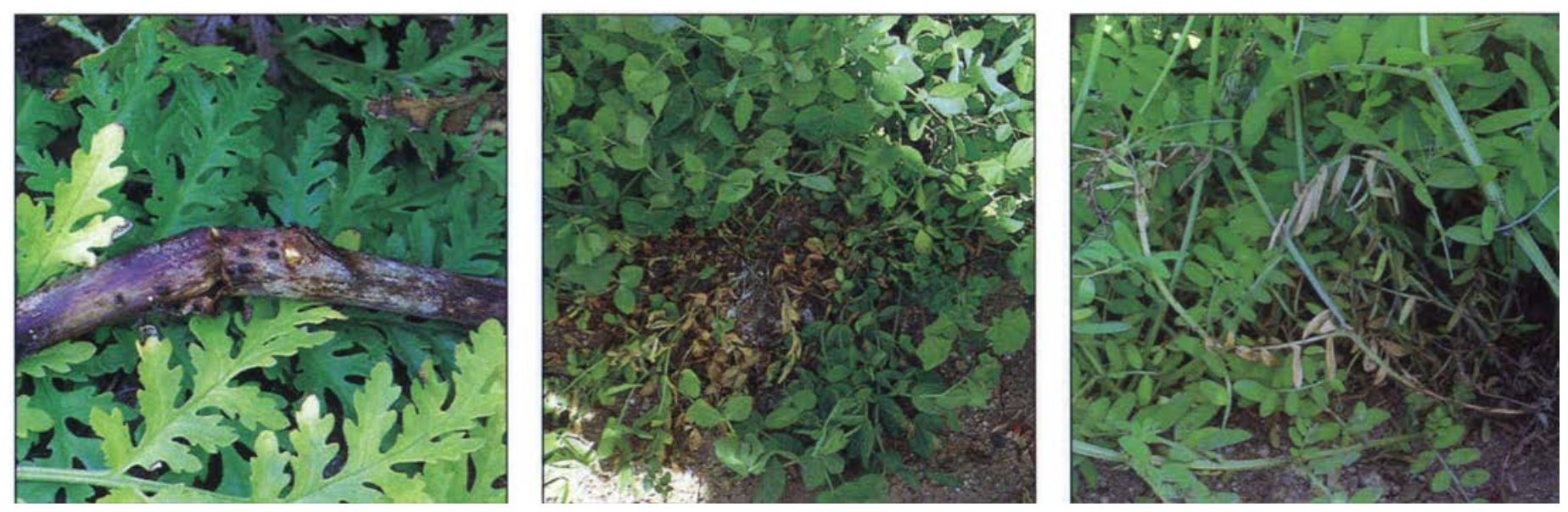

Sclerotinia-infected cover crops exhibit wilting of the plants, brown discoloration of the stems and plant death. Shown here are phacelia (left), Austrian winter pea (middle) and vetch (right).

known. Because of the lettuce industry's importance in the Salinas Valley (planted lettuce acreage in 1995 in Monterey County was 104,620 acres, with a value of $\$ 662$ million), information was needed on the interaction of new cover crop introductions and $S$. minor. The purpose of this study was to test winter cover crop species for susceptibility to $S$. minor and to assess the effect of cover crop plantings on lettuce drop incidence in field situations.

\section{Pathogenicity tests}

To test pathogenicity of S. minor on various cover crops, we produced inoculum of a lettuce isolate on sterilized potato pieces. Cultures were washed free of potato residue and the remaining sclerotia were air dried in preparation for inoculation. Fourweek-old transplants of the following cover crops were potted into 4-inch pots containing sterilized sand amended with sclerotia: phacelia 'Angelia', oilseed radish 'Nemex', lana woollypod vetch (Vicia dasycarpa), fava bean (Vicia faba) and Austrian winter pea (Pisum satioum subsp. arvense). Barley (Hordeum vulgare 'U.C. 603', a commonly used cover crop that is a nonhost of S. minor, and lettuce 'Alpha' transplants were grown and inoculated in the same way. Uninoculated cover crop and lettuce transplants were potted into sterilized sand without sclerotia. All plants were incubated in a greenhouse.

To verify that symptomatic plants were infected with $S$. minor, we conducted tissue isolations after 4, 5 and 6 weeks. Plants showing disease symptoms were removed from pots, washed free of sand particles with tap water, soaked in a $10 \%$ bleach solution for 5 minutes and then rinsed with sterile distilled water. Small pieces of crown and stem tissue were excised and placed in petri plates containing acidified potato-dextrose agar. Plates were incubated at room temperature and examined periodically for S. minor growth. We conducted the experiment twice.

Inoculated phacelia, lana woollypod vetch, Austrian winter pea and lettuce wilted and collapsed 4 weeks or later after inoculation. Crown and lower stem tissues were decayed and colonized with white mycelia, and $S$. minor was reisolated from plants of these species. No other pathogens were isolated from these plants. Uninoculated phacelia, lana woollypod vetch, Austrian winter pea and lettuce remained symptomless.

Inoculated oilseed radish, fava bean and barley did not develop disease symptoms, and S. minor was not isolated from plated stems and crowns. Results of the second experiment were the same as those of the first.

\section{Field inoculation tests}

To assess the susceptibility of cover crops in a field situation and to measure their effect on lettuce drop incidence, we established field plots at the Hartnell College Alisal Campus farm facility in the Salinas Valley in 1992-93 and 1993-94. Experimental design was a randomized complete block with five replications; each plot consisted of two 40 -inch-wide raised beds 20 feet long. For the 1992-93 experiment, all plots were infested with sclerotia prior to planting by producing inoculum of the $S$. minor isolate as previously described. Dried sclerotia that passed through $0.0787-$ inch $(2.00-\mathrm{mm})$ but not through 0.0331 -inch $(0.85-\mathrm{mm})$ aperture brass sieves (USA Standard Testing Sieves no. 10 and 20 , respectively) were placed into two seed lines on each raised bed at 0.5 inch depth using an EarthWay Precision Seeder. Inoculum was added at the rate of 40 sclerotia/foot for each seed line.

Following plot infestation, we direct-seeded plants into the same two seed lines using a Cole Planet Jr. hand planter in November 1992. Treatments were the following: phacelia 'Angelia', oilseed radish 'Nemex', barley 'U.C. $603^{\prime}$, lana woollypod vetch, purple vetch, fava bean, Austrian winter pea, fallow and unthinned lettuce 'Parris Island Cos.' In this experiment, the lettuce plots were left unthinned so that plant biomass would approach that of some of the cover crops. One day prior to planting, leguminous cover crops (two vetch species, fava bean and Austrian winter pea) were treated with a slurry of pea, vetch and lentils rhizobium inoculum.

Cover crops and lettuce were grown to maturity and evaluated for disease incidence in March 1993 by determining the total number of plants and the number of plants showing $S$. minor infection in four 1-bed-by-3-foot sections per replication. Symptomatic plants were collected and tested for $S$. 
minor as previously described. Plants were then incorporated using a power spader, which maintained plot integrity and prevented interplot mixing of soil and plant residue. Following crop residue decomposition and bed reshaping, lettuce 'Alpha' was planted in two seed lines per bed in May 1993, thinned and grown according to commercial practices, and evaluated for lettuce drop incidence in August by determining the percent infected lettuce in each plot.

In preparation for the 1993-94 experiment, lettuce in the 1993 plots was incorporated with a power marvin incorporator, which minimized interplot mixing. Plots were left as listed beds until bed shaping and cover crop planting in November 1993. Cover crops were planted in the same respective plots as the previous season, resulting in 2 consecutive years of the same cover crop per plot. Cover crops and the subsequent lettuce crop were planted, grown and evaluated as described for the 1992-93 experiment. For both experiments, fungicides were not applied during any phase of the experiment.

Disease incidence for the cover crops was similar for 1993 and 1994 (table 1), with phacelia, lana woollypod vetch, purple vetch and Austrian winter pea becoming infected. In both years the unthinned lettuce was severely diseased. S. minor was reiso- lated from diseased phacelia, lana woollypod vetch, purple vetch and Austrian winter pea. No other pathogens were isolated. Oilseed radish, barley and fava bean remained symptomless and were not infected by $S$. minor, with the exception of one fava bean plant.

Diseased cover crop plants exhibited the typical symptoms of $S$. minor infections. Brown, water-soaked lesions developed on crowns and lower stems. Lesions often girdled the plant, resulting in wilting and plant collapse. Older stem lesions dried and became dark brown or, in some cases, light tan in color. On diseased stems, white mycelia grew where stems were in contact with soil, and diagnostic small black sclerotia later developed on outer stem surfaces and inside the hollow stems. Attached, senescing leaves drooped to the ground and also exhibited sclerotial development.

In the 1993 field experiment, lettuce plots previously planted to phacelia, lana woollypod vetch, Austrian winter pea and unthinned lettuce had significantly higher lettuce drop incidence than did fallow control plots (table 1). In 1994, incidence of lettuce drop was significantly greater following only phacelia (table 1).

\section{Soil inoculum assessment}

To evaluate the effect of cultivars on soil sclerotia populations, soil

\begin{tabular}{|c|c|c|c|c|c|c|}
\hline \multirow[b]{2}{*}{ Cover crop } & \multicolumn{2}{|c|}{$\begin{array}{l}\text { Disease of } \\
\text { cover crop* }\end{array}$} & \multicolumn{2}{|c|}{$\begin{array}{l}\text { Mean sclerotia/ } \\
3.5 \mathrm{oz} \text { soil } \dagger\end{array}$} & \multicolumn{2}{|c|}{$\begin{array}{l}\text { Disease of subsequent } \\
\text { lettuce crop } \neq\end{array}$} \\
\hline & $\overline{1993}$ & 1994 & $1 \overline{993}$ & 1994 & 1993 & 1994 \\
\hline & \multicolumn{2}{|c|}{$\%$} & & & \\
\hline Phacelia & 13.9 & 21.4 & 3.4 & 7.2 & 20.6 & 39.4 \\
\hline Oil seed radish & 0.0 & 0.0 & 0.0 & 2.8 & 14.8 & 24.3 \\
\hline Barley & 0.0 & 0.0 & 0.6 & 1.4 & 11.2 & 18.0 \\
\hline Lana woollypod vetch & 18.4 & 27.4 & 5.0 & 8.0 & 22.6 & 31.9 \\
\hline Purple vetch & 17.2 & 19.0 & 2.6 & 7.2 & 17.2 & 26.5 \\
\hline Fava bean & 0.6 & 0.0 & 6.2 & 2.8 & 8.4 & 18.6 \\
\hline Austrian winter pea & 30.3 & 36.5 & 3.2 & 4.6 & 32.4 & 27.7 \\
\hline Romaine lettuce & 96.9 & 82.0 & 29.0 & 6.6 & 23.4 & 25.4 \\
\hline Fallow control & - & - & 1.8 & 3.0 & 11.4 & 18.9 \\
\hline L.S.D. $(P=0.05)$ & 5.5 & 8.0 & 11.9 & N.S. & 9.2 & 13.1 \\
\hline
\end{tabular}

"Ratio of the number of plants infected with $S$. minor to the total number of plants evaluated, expressed as percentages. In each replication, plants were evaluated in four 1-bed-3-ft sections and the values averaged.

† Mean number of sclerotia per $3.5 \mathrm{oz}(100 \mathrm{~g})$ soil sample. Samples were collected just prior to the planting of the lettuce crop. Eight soil cores were taken per plot and bulked into a composite sample. Samples were processed and assayed for $S$. minor sclerotia.

$\ddagger$ Ratio of the number of lettuce plants infected with $S$. minor to the total number of plants evaluated, expressed as percentages. All lettuce plants in the 2-bed-20-ft plots were evaluated and the values averaged.

samples were collected in May of both 1993 and 1994, just prior to the planting of lettuce. In each plot, eight 10 inch-deep soil cores were removed from plant rows using a 1-inch-diameter soil probe. The eight cores from each plot were bulked into one composite sample, mixed thoroughly, divided into $3.5-\mathrm{oz}(100-\mathrm{g})$ aliquots, soaked in a $1 \%$ Calgon solution and screened for sclerotia. Sclerotia were collected and counted with a dissecting stereomicroscope at $10 \mathrm{x}$ magnification.

In the 1993 field experiment, only unthinned lettuce plots had significantly more sclerotia than fallow control plots, and no significant differences were observed between the cover crop treatments (table 1). In 1994, no significant differences in number of sclerotia were observed between any of the treatments (table 1).

\section{Disease in a commercial field}

In 1993 and 1994, disease incidence of cover crops and lettuce was measured in a commercial field in the Salinas Valley that had a history of lettuce drop and was planted with replicated sections of cover crops intended for nitrate leaching studies. Experimental design was a randomized complete block with three replications having plot sizes of four raised beds, each 40 inches wide and 1,090 feet long. Cover crop treatments were phacelia, rye (Secale cereale 'Merced') and fallow that were planted in December in the same plots for 2 consecutive years.

Phacelia plots were evaluated for $S$. minor infections when the cover crops approached maturity in March of both years. Disease incidence was deter-

\begin{tabular}{|c|c|c|}
\hline \multicolumn{3}{|c|}{$\begin{array}{l}\text { TABLE 2. Lettuce drop incidence in a } \\
\text { commercial lettuce field in the Salinas Valley } \\
\text { following phacelia, rye and fallow cover crop } \\
\text { treatments in } 1993 \text { and } 1994\end{array}$} \\
\hline \multirow[b]{2}{*}{ Cover crop } & \multicolumn{2}{|c|}{ Lettuce drop disease * } \\
\hline & 1993 & 1994 \\
\hline & \multicolumn{2}{|c|}{...................... } \\
\hline Phacelia & 8.5 & 0.7 \\
\hline Rye & 2.0 & 0.3 \\
\hline Fallow & 4.2 & 1.4 \\
\hline L.S.D. $(P=0.05)$ & 1.4 & 0.6 \\
\hline \multicolumn{3}{|c|}{$\begin{array}{l}\text { Ratio of the number of plants infected with } S \text {. } \\
\text { minor to the total number of plants evaluated, ex- } \\
\text { pressed as percentages. In each replication, plants } \\
\text { were evaluated in four } 2 \text {-bed- } 100 \text {-ft sections and } \\
\text { the values averaged. }\end{array}$} \\
\hline
\end{tabular}




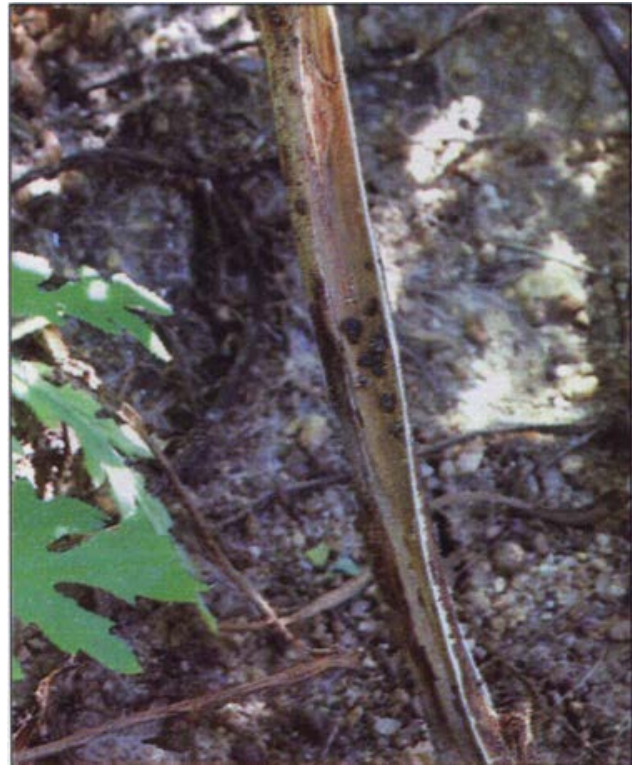

Sclerotia are present either on the outer surfaces or inside hollow stems of the plants.

mined by counting the total number of phacelia plants and the number of plants showing infection by $S$. minor in 15 1-bed-by-3-foot sections per replication. Symptomatic plants were collected and tested for the pathogen as previously described.

Following incorporation of the cover crops in mid-March of both years, the grower-cooperator planted 'Amigo' lettuce in early April. In early June, the incidence of lettuce drop was determined each year in all treatments by counting the total number of lettuce plants and the number of infected plants in four 2-bed-by-100-foot sections per replication. The four values were used to derive a mean disease incidence per replication.

In 1993, S. minor-infected phacelia were not observed. However, when the field was again planted to phacelia the following winter, a mean disease incidence of $1.8 \%$ was detected in the phacelia planting. Symptoms of diseased plants were similar to those found in the inoculated field study, and S. minor was the only pathogen isolated from collected phacelia plants.

Lettuce drop incidence varied between the 2 years (table 2). For the 1993 crop, lettuce drop incidence was significantly higher in the phacelia plots compared to rye and fallow plots. However, in the 1994 season, lettuce drop incidence was very low, with fallow plots having the highest incidence.

\section{Conclusions}

This study demonstrated that S. minor is a pathogen of phacelia, lana woollypod vetch and Austrian winter pea cover crops in California. In artificially infested plots, phacelia plantings were associated with significantly higher lettuce drop incidence in both seasons. Lana woollypod vetch and Austrian winter pea were associated with higher lettuce drop incidence in the first year only. Previous reports indicated that purple vetch was also associated with higher levels of lettuce drop in the Salinas Valley. Growers whose fields have high inoculum levels of S. minor should therefore use caution in the selection of cover crop species.

Conversely, greenhouse and field inoculations failed to result in S. minor infections of oilseed radish, barley and fava bean cover crops. For both the 1992-93 and 1993-94 field experiments, lettuce drop incidence in these three cover crop treatments was not significantly different from that for fallow treatment plots. It is apparent that these three cover crops are not hosts to the lettuce drop pathogen, and that they can be safely incorporated into lettuce rotations.

Our evaluations confirmed that naturally infected phacelia plants were present in commercial lettuce fields in the Salinas Valley. However, the impact of phacelia winter cover crop plantings varied, and phacelia plots were associated with significantly higher lettuce drop in 1 year only.

Although our data on sclerotia numbers were inconclusive, further investigations are needed to clarify how phacelia, Lana woollypod vetch, Austrian winter pea and other susceptible cover crops might contribute to the inoculum load and epidemiology of $S$. minor in lettuce fields. This is particularly important because of recent findings that other lettuce rotation crops such as basil, cauliflower, endive and escarole, fennel and radicchio are susceptible to the same pathogen and might also add inoculum to the soil.

Because cover crops may play a significant role in the epidemiology of soil-borne diseases, both organic and conventional growers should be aware of disease symptoms developing during cover crop growth. This would entail periodic monitoring of the cover crop. Organic lettuce producers must be especially cautious because they cannot use conventional protectant fungicides to shield lettuce from higher S. minor populations that might result from cover crop infection and incorporation of infested biomass.

When selecting cover crops, growers need to consider a number of factors, including soil conditioning benefits, plant nutrition aspects and pest management advantages. This can lead to a complex decision-making process. Oilseed radish, for example, offers the advantages of not being a host for S. minor and being a potential trap crop for sugarbeet cyst nematode (Heterodera schachtii). However, this cover crop species is a host to the clubroot pathogen (Plasmodiophora brassicae) and to two species of rootknot nematodes (Meloidogyne incognita and $M$. javanica). Phacelia is not a host to cyst nematode, but it is susceptible to root-knot nematode and, as shown in our study, is a host to $S$. minor. While vetch species are good suppliers of nitrogen, they are also hosts of $S$. minor and Meloidogyne species and can allow Pythium and Rhizoctonia populations to increase. In choosing cover crop species, the degree of susceptibility to pests and diseases and the relative importance of these factors for subsequent agronomic crops must be carefully evaluated.

S.T. Koike is Plant Pathology Farm Advisor, W.E. Chaney is Entomology Farm Advisor and J.I. Inman is retired Farm Advisor, Monterey and Santa Cruz counties; R.F. Smith is Small Farms Farm Advisor, San Benito County; L.E. Jackson is Associate Professor and Specialist and L.J. Wyland is Staff Research Associate, Department of Vegetable Crops, UC Davis. This research was supported by the Sustainable Agriculture Research and Education Program, UC Davis, and by the USDA-EPA A.C.E. Project 91-COOP-16590. The authors thank H. Agamalian, Y.-T. Cao, S. Dacuyan, T.G. Gonzales, E.D. Oakes, J. Taylor and M. Vidauri for their assistance, and acknowledge Hartnell College for the use of their farm facility. 